Kafkas Üniversitesi Sosyal Bilimler Enstitüsü Dergisi

Kafkas University Journal of the Institute of Social Sciences

Bahar Spring 2020, Sayı Number 25, 51-70

DOI:10.9775/kausbed.2020.004

Gönderim Tarihi: 03.03.2020

Kabul Tarihi: 19.04.2020

HOWARDS END: THROUGH THE LENSES OF BOURDIEUSIAN CAPITAL THEORY UNDER THE GUISE OF MODERNISM ${ }^{1}$

\title{
Howards End: Modernizm Kisvesi Altında Bourdieu'nun Kapital Kuramı Bakış Açısıyla
}

\section{Dilek TÜFEKÇİ CAN}

Assist. Prof. Dr. Balıkesir University, Necatibey Faculty of Education

English Language Teaching Department tufekci@balikesir.edu.tr

ORCID ID 0000-0001-8067-6032

Çalışmanın Türü: Araştırma

\begin{abstract}
E. M. Forster's novel "Howards End" implicitly employs Pierre Bourdieu's capital theory with its concepts such as economic, social, cultural and symbolic capital by endowing its characters with different culturally embedded habitus. The characters, each of which belong to upper, middle and lower classes, are the representatives of their hierarchically structured classes. While each of the characters are donated with certain levels of capital, they struggle to compete to be powerful in the Edwardian society where injustices occur in all spheres of life. Thus, this paper attempts to analyze Bourdieusian manners and perception of fe(males) with an emphasis on modernity.
\end{abstract}

Keywords: E. M. Forster, Howards End, Pierre Bourdieu, Capital Theory, Modernity

Öz

E. M. Forster'in "Howards End" adl romanı dolaylı olarak Pierre Bourdieu'nun ekonomik, sosyal, kültürel ve sembolik kapital kavramlarını kullanmaktadır. Roman karakterlerini farklı kültürel alışkanlıklarla (habitus) donatarak aslında Bourdieu'nun kapital kuramını işlemektedir. Üst, orta ve alt sınıftan olan karakterlerin tümü hiyerarşik biçimde yapılandırılmıs sinıflart temsil ederler. Bu karakterlerin her birine belirli seviyelerde kapital verilse de yaşamın her alanında haksızlıkların olduğu Edward dönemi toplumunda güçlü olmak için mücadele etmek zorunda kalırlar. Bu çalışma, romandaki modernizme vurgu yaparak kadın ve erkek karakterlerin Bourdevari tavır ve algılarını ortaya çıkarmayı amaçlamaktadır.

Anahtar Kelimeler: E. M. Forster, Howards End, Pierre Bourdieu, Kapital Kuram, Modernizm

\section{INTRODUCTION}

E. M. Forster's fourth novel entitled Howards End (1910), which is considered among the middle phase novels, is mainly about relationships. The book's epigraph, "Only connect..." undoubtedly indicates that the

\footnotetext{
${ }^{1}$ This study is a reviewed and revised version of an unpublished $\mathrm{PhD}$ dissertation on the novels of E. M. Forster, which is to be submitted to Istanbul Aydın University, English Language and Literature program in order to fulfil the requirements of a graduate student.
} 
characters in the novel endeavour, but in vain, to find a common ground in a disconnected society. Gordon states that "'Only connect' is the book's superscript, after all, and it is the connection of the male and female that is the true map to the land of sanity" (2004, p. 97). From another perspective, Howards End (HE) relatively deals with "the confrontation of two mutually and paradoxically sympathetic and antithetical cultures, those of England and Germany" (Firchow, 1981, p. 50). Yet, to Sugate, the theme of the novel is no more than a love:

"Howards End", in a way, is all about love and of kinds of love: love between sisters, love between husbands and wives, love for home, love for one's country, extramarital love and love for anything to everything. Forster believes in love as a unifying power, which connects the two opposing characters in his novel (2012, p. 194).

Howards End, which was created between the death of Queen Victoria and the World War I, evidently deals with the themes of capital accumulation, familial linkages and, love and death by bringing metaphysical and psychological connotations of its characters to the forefront. In this novel, Forster reveals the fragmentation of the self in a materialistic world where the social (ex)changes regarding human relations deeply affect the characters in the Edwardian society. Throughout the novel, Forster reflects the unrest of the society due to the growing interest in materialism and presents a gloomy atmosphere and a pessimistic account of London life in the early $20^{\text {th }}$ century by juxtaposing English and German cultures.

In Howards End, Forster uses the German elements which are also found in his biography entitled E. M. Forster: A Life (1978) by P.N. Furbank. More explicitly, from 1905 to 1906, Forster lived in Germany where he worked as a tutor to the children of Elizabeth von Arnim for about a year. Subsequently, Forster uses all his reminiscences about Germany in Howards End. Yet, it would neither be appropriate to call Howards End as Forster's German novel nor it would be inappropriate to do so, even if "[t]hree of the chief characters and the two protagonists, Helen and Margaret Schlegel -are half-German, bear obviously German names, are extremely conscious of their German ancestry and heritage, and are frequently associated with visits to and from Germany and their German relatives" (Firchow, 1981, p. 50).

Most of the critics commonly agree that Howards End deals with 
morality and gender on the surface. Malcolm Bradbury states that Howards End navigates morality in a complicated society as it is "about the circumstances in which the moral life [...] can be led in society, about the compromises which it must effect with itself if it is to do so, and about the moral imaginative value of making such compromises" (1966, p. 130). To Sugate, Forster deliberately "intertwines the theme of gender" in the novel because "He, like in his earlier novel The Longest Journey and A Room with a View, seems to be preoccupied with the gender issues in Howards End. He goes to critiquing the Edwardian gender roles by playing out the themes of masculinity and femininity repeatedly" (2012, p. 187). As inferred, Forster's novel revolves around a number of themes such as (non)connection, distinct cultures, (un)mutual love, materialism, capital accumulation, fragmentation of the self, and so on.

E. M. Forster presents his characters in Howards End as life-like ones whose traits and manners are representatives of Edwardian society as stated by Frank Kermode: "[...] in Howards End the characters are presented as free individuals, with minds of their own" (2009, p. 11). Indeed, Forster presents his characters with their free wills and common sense. He creates real-like characters whose manners are commonly in congruent with the norms of mimetic theory. Kermode also adds that the novel contains a large number of "authorial reflections" such as "wise sayings about love, class and culture, panic and emptiness, prose and passion, connecting and not connecting, straightforward announcements of the Forsterian way of looking at the human condition" (2009, p. 12-13). To Madran, Forster particularly narrates "the universal feelings and behaviour of the individual, such as man's divided nature, the loss of identity, the discontinuance of social relations, loneliness, and fear" by enforcing the characters to "find out their own solutions to the problems they face" (2004, p. 198) in Howards End. Indeed, the reason why Forster penned one of his most well-structured novels, namely Howards End is to expose the desperateness of his characters in a world where the people are trapped under the strong influence of modernism.

The novel mainly revolves around three families; the Wilcoxes, Mr. Henry and Mrs. Ruth Wilcox with their two sons named Charles and Paul, and a daughter Evie; the Schlegels, somewhat a family of women, Helen and Margaret Schlegel and their aunt Mrs. Munt, and a brother Tibby; and last of all the Bast family, Leonard and Jacky. Whereas the Wilcoxes, as the representative of upper class, are presented as insensitive and rigid, the Schlegels, as the intellectual upper-middle class, are as soft and romantic, 
and the Bast family, as the representative of the working class, is as poor and desperate in the Edwardian society.

In the light of all these accounts, it is significant to reveal that the characters in Howards End are in conflict with the cultural codes and social norms of the Edwardian society. They struggle to realize their inner self in a world where the social and cultural expectations are gradually changing because of the capitalist new world order. Thus, Forster, as an intuitive writer, attempts to expose to what extent the identities of both male and female characters are evolved from conventionality to modernity and from spirituality to materiality/ in the novel. Through race-conscious, classconscious and gender-conscious characters in the Edwardian period, Forster vividly creates his characters by juxtaposing different cultures and by exposing interchangeable relationships in a modern society in Howards End.

This paper attempts to reveal the perceptions and manners of female and male characters who are under the threat of modernism by considering the cultural codes and societal norms in the Edwardian society through E. M. Forster's novel Howards End. In order to do this, this paper also employs Pierre Bourdieu's capital theory and exposes the perceptions and manners of the characters by an in-depth analysis.

\section{BOURDIEUSIAN CAPITAL THEORY}

Pierre Bourdieu (1930-2002), a French sociologist, philosopher, anthropologist, and a maverick intellectual of his time, is specifically involved in discovering the formative roots of class distinctions and power structures. In general sense, his works commonly emphasize that social and cultural backgrounds are significant for the individuals in order to gain status and power in any given society. In regard to the concept of capital, as the title of this part also includes, it is of great importance to mention briefly about the contributions of Pierre Bourdieu whose works are deeply affected by those of Emile Durkheim. Firstly, Bourdieu focuses predominantly on the functionalism and structuralism and then, he becomes much more concerned on the issues such as education, labour, literature, language and philosophy among many others which take their theoretical background from Martin Heidegger, Edmund Husserl, Karl Marx and Max Weber and so on. What makes Bourdieu unique in particularly literary studies is his best-known work entitled Distinction: A Social Critique of the Judgement of Taste (1979) among many others, unambiguously, which argues that judgements of tastes are mostly related to social position or social positionings of the individuals. He emphasizes the influence of both external social structures 
and subjective experience of the individuals in judging tastes.

Pierre Bourdieu's views on labour theory of capital are, in some sense, different from those of Marx, who sees capital as money used to buy something in order to sell it again to make a profit. To Bourdieu, capital is something accumulated and transmitted to the next generations in its general meaning. Rather than its economic sense, Bourdieu uses the term in order to define social phenomena. Because he considers capital as a source which leads to wealth and then, power. He strongly argues that whereas economic capital is immediately and directly convertible into money (Bourdieu, 1986), the cultural capital and social capital are on certain conditions convertible. What makes Bourdieu's contribution distinctive among many other scholars is his exceptional notions on cultural capital which he thought it is connected to class hierarchy.

Pierre Bourdieu, who believes that the social world is accumulated history, divides capital in three parts namely, social capital, cultural capital and economic capital interchangeably in his work entitled The Forms of Capital (1986). In general sense, while economic capital is to do with money, cultural capital is educational qualifications and, social capital is social connections. Moreover, he distinguishes cultural capital into three forms. Explicitly, cultural capital exists in the embodied state, namely, in the form of long-lasting dispositions of the mind and body; in the objectified state, explicitly, in the form of cultural goods such as pictures, instruments and books; and lastly, in the institutionalized state, that is, in the form of academic credentials or professional qualifications, which facilitate the conversion of cultural capital into economic capital (Bourdieu, 1986, p. 243). In relation to cultural capital, Bourdieu thinks that different social classes allocate different investments on culture.

In order to appreciate cultural capital of Bourdieu, the multidimensionality and transformability of the different type of capitals should also be taken into account. According to Bourdieu, in the embodied state, the accumulation of cultural capital is what is called culture in general, or cultivation. And, "it [the cultural capital in the embodied state] implies a labour of inculcation and assimilation, costs time and time that must be invested personally by the investor" (1986, p. 244). Bourdieu also adds that it is not something which is acquired just like a muscle or a suntan. Rather, it involves an effort of personal investments including privatisation, renunciation and sacrifice. Accordingly, Bourdieu states that "cultural capital can be acquired, to a varying extent, depending on the period, the society, and the social class, in the absence of any deliberate inculcation, and 
therefore quite unconsciously" (Bourdieu, 1986, p. 243). Whereas in the objectified state, the cultural capital such as writings, paintings, instruments, etc. becomes transmissible in its materiality, in the institutionalized state, the cultural capital is related to academic qualification or a certificate of cultural competence that bestows "its holder a conventional, constant, legally guaranteed values with respect to culture" (Bourdieu, 1986, p. 243). As can easily be inferred, Bourdieu's classification of capital in general sense leads to the basic formation of capital theory, which is distinctively different from those of the Marxist approaches.

Bourdieu describes social capital as "the aggregate of the actual or potential resources that are linked to durable network of more or less institutionalized relationship of mutual acquaintance and recognition, or in other words, to membership in a group" (1986, p. 244). In other words, social capital can only be achieved through interpersonal relationships, a shared sense of identity, shared norms, mutual understanding, mutual trust and cooperation. Moreover, social capital refers to connections among individuals. Furthermore, these connections or relationships "may also be socially instituted and guaranteed by the application of a common name (the name of a family, a class, or a tribe or of a school, a party, etc.) and by a whole set of instituting acts..." (Bourdieu, 1986, p. 244). Accordingly, social capital can mainly be acquired through the network of acquaintances in the society.

After explicating Bourdieusian notion of capital in general aspects, it is important to state that the rest of this paper aims to decode the perceptions and manners of the Edwardian characters in the Edwardian society in Howards End by applying capital theory of Pierre Bourdieu and by revealing the impacts of modernism on the characters.

\section{BOURDIEUSIAN CAPITAL THEORY UNDER THE GUISE OF MODERNISM}

In Howards End, modernism is revealed through a number of incidents whose connections are deeply rooted in both industrialism and capitalism. The characters, who are under the strong influence of modernism, feel insecure and desperate in a world where the economic capital of modern society has expanded at an immense speed. As is the case in the Edwardian period, Howards End presents the corruption of the identity in a world where the needs and demands of the individuals to Bourdieusian social, cultural and economic capital gradually increase in the society. The change firstly in the economics, and secondly in the culture, and 
finally in the society results in the reluctance of the characters in maintaining social and familial relationships. As far as social capital is concerned, it is apparent in the novel that the characters' unwillingness to form familial relationships is to do with some aspects of modernism such as subjectivity and/or unstable identity. The characters such as Helen, Tibby and Paul display the aspects of subjectivity and/or unstable identity predominantly. These three characters are either unable or unwilling to form families, which means that in Bourdieusian terms, they are not eager to invest their social capital.

At the very beginning of the novel, even though Helen and Paul fall in love and decide to form a family, the fear of Paul prevents him from marrying. After Paul leaves for Nigeria to work, namely to invest his family's economic capital through the means of imperialism, and gets involved in business, he never thinks of forming any familial relationship till the end of the novel. Briefly, it can be inferred that neither Paul nor Helen gives importance to social capital. On the issue of social capital, Bourdieu reveals that "[e]very group has its more or less institutionalized forms of delegation which enable it to concentrate the totality of the social capital, which is the basis of the existence of the group [...]" (1986, p. 251). As is the case in Howards End, the three families act as the institutionalized forms of members whose existences are connected to each other. Besides, Bourdieu believes that the head of the family, either the paterfamilias, or the eldest and/or the most senior member is implicitly considered as the only person entitled to speak on behalf of the family group at the most basic of level of the institutionalization (Bourdieu, 1986). Accordingly, the Schlegels are considered as a family with its members as suggested by Bourdieu. And, the eldest person in the family, Mrs. Munt, the Schlegels' eldest aunt, speaks on behalf of Helen's potential marriage with Paul. For instance, Mrs. Munt's interrogative questions about the younger boy of the Wilcoxes when she hears that her niece Helen intends to marry him indicate that she is the one who supports institutionalized state of the cultural capital. Because she believes that marriage is going to bestow its possessor a status, which is "conventional, constant, legally guaranteed values with respect to culture" (Bourdieu, 1986, p. 243). The following quotation by Mrs. Munt directly shows how inquisitive she is about her niece:

Margaret, if I may interfere, don't be taken by surprise. What do you think of the Wilcoxes? Are they our sort? Are they likely people? Could they appreciate Helen, who is to my mind a very special sort of person? Do they care about 
Literature and Art? That is most important when you come to think of it. Literature and Art. Most important. How old would the son be? She says 'younger son.' Would he be in a position to marry? Is he likely to make Helen happy? (HE, 10).

Apart from social capital, this quotation also implies Mr. Munt's perspectives on both cultural capital and economic capital of the Wilcoxes. More explicitly, all these inquiries indicate how much the Schlegels give importance to cultural capital rather than the material one in the novel. Because Mrs. Munt explicitly says that literature and art are the most important capital of all. Reasonably, the Schlegels appreciate the humanistic values compared to the economic values. Unlike the Schlegels, the Wilcoxes are characterized by economic capital, they believe that "Art and literature, except when conducive to strengthening the character, [are] nonsense" ( $H E$, 25). Rather than being knowledgeable about literature or art, say, Shelly the poet, the Wilcoxes prefer economic capital and they simply ignore the significance of cultural capital as well. Because the Wilcoxes have already solved the close relationship between economic capital and power; and they act accordingly. In other words, when the economic capital increases, the power they have also increases in the Edwardian society.

In the previous paragraph, it is stated that Helen, one among the three other characters who disregard social capital, is presented as a woman who does not care about the institutionalized state of the cultural capital in the novel. Because she quits immediately Paul. Apart from Paul and Helen, Tibby is presented as an intellect who searches for his identity and conducts research at Cambridge, a place where he recedes from reality. In Bourdieusian aspects, Tibby can be considered as a man who gives importance to cultural capital by legalizing his education at a university. Just like Helen and Paul, he shows no signs of interest in forming familial bondage, which means that he has no interest in social capital. As seen these three characters fail in forming familial relationships, or they are presented as characters whose social capital has nothing to do with marriage. However, their loss of interest in forming family is reflected in a Sunday paper in the novel, "very serious thing this decline of the birth-rate in Manchester" ( $H E$, 51). And, it is also added that "if this kind of thing goes on the population of England will be stationary in the 1960" (HE, 51). In the Edwardian period, a reality which is also placed in the newspaper clearly informs that the young who refuse marrying at the age of marriage ignore the value of social capital. Furthermore, instead of marrying (social capital), whereas Tibby prefers 
having an education at the university (institutionalized state of cultural capital), Paul prefers going abroad to increase his family's profit (economic capital). In the novel, the perceptions of the young not to marry is also presented among the bad effects of modernism. In the novel, the subjectivity, which is identifiable in the acts of Tibby and the unstable identity, which is discernible in the relationship between Helen and Paul are the implications of modernism.

As has already been known, the upper-class Wilcoxes make a fortune through the colonies by sacrificing their own identities and humanistic values to materialism. The intellectual Schlegels, as the representatives of upper-middle class, devote themselves to the humanistic values. Besides, they fail in their attempt to accumulate more wealth. The Basts, as the representatives of working class, is exploited by the upper and upper-middle class as a result of capitalism. Among these families, the Basts are the ones who have to suffer from the inescapable effects of capitalism in their lives. According to Helen, Leonard "is married to a wife [an intended wife Jacky] whom he doesn't seem to care for much. He likes books, and what one may roughly call adventure, and if he had a chance - but he is so poor. He lives a life where all money is apt to go on nonsense and clothes" (HE, 141-142). This quotation reveals that Leonard is unable to increase his cultural capital because he is poor. Furthermore, he has had to marry a wife from the lower class, which shows his own inclination to the social capital. Namely, as he is a poor man, he feels closer to the lower class not the uppermiddle class. Furthermore, his lack of economic capital also prevents him reading books as well. In Bourdieusian terms, Leonard, a man of working class, who loses both his job and life at the end, believes that he can never and ever transfer his cultural capital by reading books and going to the concerts. He realizes that he lacks cultural capital. Because "With an hour at lunch and a few shattered hours in the evening, how was it possible to catch up with leisured women, who had been reading steadily from childhood? (HE, 42-43). Kim Shirkhani explains Leonard's position on Bourdieusian terms as such:

Leonard's Bourdieuian perspective on his problems illustrates his own acuity and also undercuts the ability of the cultured and well educated to congratulate themselves on being the way they are. He sees what are often taken to be ineffable talents as, instead, early-acquired skills, and, in generalizing beyond his own case, he also clarifies the scope of the problem, suggesting that even if he can 
succeed as a special case, by being taken up as the Schlegels' protege, there would remain an entire class of others who desire yet never have such an opportunity $(2008,207)$.

Besides, Leonard also knows that he lacks social capital even if he desires to get in touch with the people from the upper-middle class. More explicitly, he is unable to carry out a conversation with them as he lacks cultural capital: "His brain might be full of names, he might have even heard of Monet and Debussy; the trouble was that he could not string them together into a sentence, he could not make them 'tell,' he could not quite forget about his stolen umbrella" (HE, 43). As far as cultural capital is concerned, the length of the time an individual allocates for the acquisition process depends on the time as stated by Leonard, whose time is rather limited for a reading. Compared with the females in the upper-middle class in regard to cultural capital, Leonard is undeniably in a desperate position. In his inner voice, he sighs: "If only he could talk like this, he would have caught the world. Oh, to acquire culture! Oh, to pronounce foreign names correctly! Oh, to be well informed, discoursing at ease on every subject that a lady started! But it would take one years" $(H E, 42)$. Indeed, he hopes to be able to talk like Margaret or to have read all the books Helen speaks about. Yet, Leonard is aware of the fact that he will never be able to reach the cultural capital of the Schlegels. But he is not sure whether he is able to maintain his social capital with the sisters. Thus, Leonard treats Margaret and Helen with the utmost courtesy to gain their respect because he believes that he will only be able to connect with the upper class if he does this.

Leonard attempts to hide his cultural capital for fear of presenting a fake social status, which is displayed in a number of conversations between him and Margaret on art, painting, music, Wagner and Monet. As a member of lower-class, "Leonard [is only] acting the concert-goer, and acting up to the people he meets", but unfortunately he is unsuccessful in keeping the conversations going with the upper-middle class people. Because he lacks cultural capital, namely "familiarity with the legitimate culture within a society" as Pierre Bourdieu (1984) labelled the term. The cultural capital inculcated in the early childhood period is what Leonard lacks. According to Crews, Leonard is "a symbol of the worst effects of modern capitalism, which encourages people like Leonard to be dissatisfied with their circumstances and at the same time frustrates their desire for recognition" (1967, p. 118).

Throughout the novel, Leonard has to cope with class-conscious 
manners of the Schlegel sisters as they consider him a "social problem" rather than an "individual being". For instance, the Schlegels think that Leonard's poverty can be solved through debates over the luncheons or afternoon teas. They also pity him because he has a problematic love affair with a fallen woman from extremely lower class. In the meanwhile, Leonard struggles to appeal to upper class and its culture because he thinks that reading particularly, the works of Ruskin and Robert Louis Stevenson and, attending the performances hold in Queen's Hall Concerts will enhance him to be connected to upper-class socially but for culturally. Jeffrey Weeks highlights that how the identity of the subordinated is in struggle with the dominant power with these words:

Identity is not inborn, pregiven, or 'natural'. It is striven for, contested, regulated, and achieved, often in struggles of the subordinated against the dominant. Moreover, it is not achieved by an individual act of will, or discovered hidden in the recesses of the soul. It is put together in circumstances bequeathed by history as much as by personal destiny $(1989,207)$.

In the novel, when analysed Leonard's life in accordance with the social, cultural and economic capital of Bourdieu, it is obvious that he has never been successful in increasing any of these capitals in his lifetime, even if he strives for them. Yet again, he is presented as man who prefers spending every penny he has gained for cultural capital even if he is unable to resist capitalism as a working-class man, as narrated in the following part:

Leonard stood wondering whether he would take the tram as far as a penny would take him, or whether he would walk. He decided to walk - it is no good giving in, and he had spent money enough at Queen's Hall - and he walked over Westminster Bridge, in front of St. Thomas's Hospital, and through the immense tunnel that passes under the South-Western main line at Vauxhall (HE, 50).

In the quotation above, Leonard's choice of spending money on cultural capital rather than economic capital is given purposefully. Indeed, Leonard wants to get most of the benefit from cultural capital so as to come closer to the upper-class. He believes that he may overcome all his problems through cultural engagement and realizes that it is impossible for him to be rich. Unlike Jacky, Leonard attempts to find peace in the libraries and concert halls as he thinks he will be able to find his way by following such 
occasions. The relationship between Leonard and Jacky about forming family, as an institutionalized state of cultural capital, is an indicative of not only economic capital but also social capital. Leonard is presented as a man who is much more impartial than Jacky to the concepts, beliefs and attitudes of a new modern society. Because he feels that it is a matter of honour for him to get married with a decent woman. Namely, marrying a decent woman is commonly regarded as a virtue of a man, as explicitly stated by Forster himself, Leonard is "the man who had no advantages, who was poor and had been made vulgar, whose early virtue had been destroyed by circumstance, whose manliness and simplicity had perished in serving the rich" (Forster, 1947, p. 306).

As seen, the Basts do not have the capacity to increase their economic capital. Henry Turner states that Leonard and his wife, Jacky, are the symbols and "figures for surplus and the human cost of capitalism" (2000, p. 339), the statement of which signifies their economic capital. Likely, Jonathan Rose reveals that "Bast is anxious and envious among the rentier intelligentsia" and adds that his attempts to acquire culture are hopeless (2001, p. 402). Indeed, the Basts show their apprehension while connecting with the Schlegels and the Wilcoxes, who live their lives from the money earned from property and investments. According to Shirkhani, Leonard is presented as "a flat and unsympathetic character, a sacrifice to a larger argument Forster is trying to make about the state of high culture in modern English society" (2008, p. 193).

Pierre Bourdieu explains the dynamics power in society by introducing a concept habitus. The habitus, an influential yet an amorphous concept coined by Bourdieu himself, is defined "as a system of dispositions to a certain practice, is an objective basis for regular modes of behaviour, and thus for the regularity of modes of practice, and if practices can be predicted" (Bourdieu, 1990a, p. 77). The habitus means a set of acquired patterns of thought, behaviour, and taste in general. It is also used in the sense of "taste for cultural objects" such as art, food, clothing, etc. Bourdieu defines the term "the past which survives in the present" (1977, p. 83), whose main concern is to do with the dynamics power in the society.

In one of his major works entitled Distinction (1979), Bourdieu argues that aesthetic sensibilities are shaped by the culturally embedded habitus; he gives an illustration about the tastes of upper-class and workingclass individuals to the fine arts; and concludes that whereas upper-class individuals have a taste for fine arts, the working class individuals are not exposed to cultural habitus; and thus, they are unable to cultivate the habitus 
for fine arts. Thus, the change in the taste, which is heavily dealt with habitus, shapes the socio-structural aspects of the society. Broadly speaking, it can be inferred that the aesthetic preferences or variables in the society lead to the emergence of class-based social groups, whose tastes are distinctively different from one another.

The tastes of the characters in Howards End are completely different from each other. In other words, the aesthetic sensibilities of the three families namely the Schlegels, the Wilcoxes and the Basts are shaped by the culturally embedded habitus of the characters. Whereas the Schlegels are the members of the German intellectuals whose culturally embedded habitus is remarkably in higher status than the other two, the Wilcoxes are the members of the English capitalist system whose culturally embedded habitus is limited to a certain degree. For instance, Leslie White reveals that "Ruth is neither 'dogmatic nor possessed of the missionary spirit.' Privy to the 'unseen' without having pursued the apparatus of high culture that Margaret and Helen have mastered - concerts, literature, discussion meetings, museums - Ruth often seems less a character than a finite spirit, a physical embodiment of the 'unseen' $(2005$, p. 52). Ruth, who is less concerned with high spirit values culturally, is presented as the binary opposition of Margaret. Thus, in the novel, the Schlegels and their social and cultural capital are revealed in regard to their German philosophy as narrated in the following quotation:
A word on their origin. They were not "English to the back-bone," as their aunt had piously asserted. But, on the other hand, they were not "Germans of the dreadful sort." Their father had belonged to a type that was more prominent in Germany fifty years ago than now. He was not the aggressive German, so dear to the English Journalist, nor the domestic German, so dear to the English wit. If one classed him at all it would be as the countryman of Hegel and Kant, as the idealist, inclined to be dreamy, whose Imperialism was the Imperialism of the air (HE, 30).

Firchow also indicates the cultural capital of the Schlegels by these words: "Hegel and Kant are viewed as representatives of a Germany anterior to Bismarck's [...]. They are associated with Father Ernst Schlegel" (1981, p. 56). As for the Basts, they are the members of the working class whose family background goes back to the agrarian society, a culturally degraded or debased group. They are also the ones who are exploited by the wealthy 
class either economically or sexually, namely, sexual exploitation of Jacky is also to revealed in the later parts of this paper.

Apropos of Bourdieusian theory, economic capital is constructed on money income in the form of either wage or profit, or both; social capital is related to intensity of social relationship, which is based particularly on mutual trust; cultural capital is to do with the educational degree of an individual which helps increasing the taste of the individual's life style. Apart from these, Bourdieu also introduces the symbolic capital, which basis its existence on the concepts such as honour, respect or recognition one holds within a culture. The symbolic capital is also commonly regarded as an analysis of the status, which indicates the economic supremacy of the upper class and socially legitimate hierarchy. For instance, in the novel, Mr. Wilcox is presented in terms of symbolic capital of Bourdieu. In the eyes of Leonard, "Mr. Wilcox was king of this world, the superman, with his own morality, whose head remained in the clouds" (HE, 252). Moreover, the volume of the social capital depends on the size of the network of connections of an individual. As a well-known man in the business spheres, it is rather discernible that Mr. Wilcox' social network is gradually increasing, and as a result, the cumulative effect of his endeavors also increases his social capital. Bourdieu $(1977,1986)$ argues that power, as the main source in a society, is a concept which can never be thought of separable from economic, social, cultural and symbolic capital. Accordingly, individuals struggle in society in order to transfer the symbolic power into economic, social and cultural power to be successful in the competition.

In society, according to Bourdieu, there are two types of struggle. The first struggle is the struggle on the distribution of economics, social and cultural capital among the individuals, groups, classes and societies. The second struggle is the symbolic struggle on the evaluation of economic, social and cultural achievements. The symbolic struggle commonly occurs among classes, which depends on one or two types of capital. Yet, it is important to note that, in Bourdieusian view, capital refers to economic, social and cultural means, such as successively, money, network of social relationship, and education, as has already been revealed. Bourdieu, by taking the assumptions of Marx, proposes that competition on the aforementioned three capitals are not equal in any respect (1970). The main reason of this inequality is the hierarchically structured societies, that is, lower, middle and higher classes.

As far as Howards End is concerned, it is apparent that the classes are distinguished from one to another in terms of Bourdieusian economic, 
cultural and social capital. The clear hierarchy of power is notable among the classes. If any individual commences with a certain amount of capital and invests them, it becomes more likely to win the competition among many other people in a particular class. Yet, the hierarchies in the society prevent individuals to compete with each other in more egalitarian terms. For instance, for someone from the lower class, it becomes rather difficult to be successful in a highly competitive society, as is the case in Leonard's life. His house is narrated as such: "Opposite the window was the door, and beside the door a bookcase, while over the piano there extended one of the masterpieces of Maud Goodman" (HE, p. 51). As deduced, even if his house is presented with its bookcase, piano and masterpieces of a well-known painter, which are the signs of cultural capital, he loses the competition and dies at the end because of the hierarchy in the society.

The hierarchy among the classes is explicitly revealed through the objects used by the classes. As an indicator of modernity, the Wilcoxes are usually proud of their ostentatious houses. Because they are always eager to flaunt their wealth by decorating their house as a sign of social capital prescribed by the upper-middle class people, as it is indicated in the following part:

The dining room was big, but over furnished [...] those heavy chairs, that immense sideboard loaded with presentation plate, stood up against [the room's] pressure like men. The room suggested men, and Margaret, keen to derive the modern capitalist from the warriors and hunters of the past, saw it as an ancient guest-hall ... (HE, 173).

In the novel, the signs of modernism are inserted in every spheres of life as they have a profound impact on the lives of the characters. Yet, apart from their houses, the Wilcoxes also show off their wealth by the motorcars that they have bought as an implication of their economic capital. According to Lucas, Forster deliberately presents the introduction of motor cars as a "symbol of intrusive, unsettling power" (1997, p. 38) in the countryside, which undoubtedly exerts a great influence on transforming the economic, social and cultural life in the Edwardian period. And on the issue of motorcars, historian Richard Overy states that "the motorization revolution ... is one of the major hallmarks of modernity, transforming social life [and] the economic system" (1990, p. 54). Similarly, Forster uses "motor-cars" as a symbol of modernity that is inevitably "linked with a strongly gendered discourse, whereby women represent fixity and stability of rural places and domestic home, with the Wilcox men representing the city, the car, the 
modernity itself' (Thacker, 2000, p. 44). Additionally, under the pretext of modernity, the motor-cars also signify the economic capital of the Wilcoxes, as the quote suggests, "Yes, he [Charles] would go up after lunch in his new motor, and the town servants, who had come down for the funeral, would go up by train", Forster implicitly reveals the distinction between the uppermiddle class and the working class in relation to their culturally embedded habitus in Bourdieusian terms. Namely, whereas the Wilcoxes use their private cars as a means of transportation, the working class have to commute by public transports such as trains.

On the aspects of economic capital, another example can also be given in order to show to what extent the Wilcoxes appear to be insensitive to issue of animal rights. Because they unwisely think that the economic capital can easily compensate the life of an animal. More obviously, when Charles Wilcox hits a dog with his car and kills it, he shows no mercy. His indifference to the dog epitomizes his priority to the economic capital. Because, according to him, the death of the dog is only related with the insurance company as soon as they pay for the damage of the car and the owner of the dog is compensated with a little money. For him, the dog is of no importance. The Wilcoxes show no concern neither for the human as "Albert will do the talking" with the owner of the dog and nor for the animals as "insurance company sees to that" $(H E, 225)$ about their car.

The Wilcoxes' enthusiasm on economic capital is presented through the manners of Henry Wilcox, which are indicatives of his choice of maintaining human relations, namely social capital. Unsurprisingly, he maintains his relationship with people on economic capital rather than social capital. Henry Wilcox's suggestion to Margaret on leaving a tip at a lunch table explicitly exposes that he rather prefers maintaining his social relations around economic capital. In one incident, Henry Wilcox attempts to explain Margaret about the importance of leaving a tip for the people from the working-class: "Tip everywhere's my motto [...]. Then the fellows know one again. Especially in the East, if you tip, they remember you from year's end to year's end" $(H E, 162)$. Accordingly, Henry uses "tipping" as an instrument to denote how human relationships can be purchased. He intensely advocates that human relationship is mainly based on economic capital. On the contrary, Margaret replies that "Perhaps it does make life more human" (HE, 162), the statement of which shows Margaret's considerate and civilized manners when compared to that of Henry.

In the course of novel, Forster deliberately unveils how the opinions and attitudes of Margaret have changed remarkably on the property and 
accumulation of money in order to juxtapose her gradual transformation from cultural to economic capital. Namely, the conversion of Margaret from cultural-based capital to economic-based capital is recognizable throughout the novel. Most probably, this conversion may have resulted in her close interaction with the Wilcoxes. Margaret's materialistic views, which give more importance to money and possessions than to spiritual values, are intensely presented in a number of narratives. According to Turner, "she [Margaret] retains a vision of the imperialist as hard worker and civilizer" (2000, p. 331). Thus, Margaret contemplates that living a wealthy life is a source of pleasure. Likewise, her views on economic capital particularly, on the importance of accumulating much more money, are exemplified through the lenses of Margaret when she forces her brother Tibby to work:

So take warning; you must work, or else you must pretend to work, which is what I do. Work, work, work, if you'd save your soul and your body. It is honestly a necessity, my dear boy. Look at the Wilcoxes, look at Mr. Pembroke. With all their defects of temper and understanding, such men give me more pleasure than many who are better equipped, and I think it is because they have worked regularly and honestly (HE, 118).

In another example, Margaret emphasizes the importance of economic capital by referring to conditions of the working women in a modern society. She assumes that the women who are working outside their houses are going to display a liberating act because “... in the last century men have developed desire for work, and they must not starve it. It is a new desire. It goes with a good deal that's bad. But in itself is good, and I hope that for women, too, 'not to work' will soon become as shocking as 'not to be married' was hundred years ago" (HE, 117). In other words, to Margaret, working is going to become an indispensable condition for women soon. As indicated in this quotation, Margaret gradually internalizes the newly adopted Edwardian manners particularly on the potential value of working for the women. Specifically, she becomes much more concerned with the issue of working women as she thinks that working is the best thing for accumulating money and acquiring property and, in return, the women will be equipped with the liberty they desire through the economic capital for which they struggle.

\section{CONCLUSION}

In conclusion, among E. M. Forster's one of the noteworthiest 
novels, Howards End implicitly employs Bourdieusian capital theory through its concepts such as economic, social, cultural and symbolic capital by endowing its characters from different culturally embedded habitus. Apart from this, the characters, each of which belongs to upper class, middle class and lower class, are the representatives of their hierarchically classes. While each of the characters are donated with certain amounts of economic, social and cultural capital, they struggle to compete to be powerful in a world where the injustices in all spheres of life occur. Whereas the lowerclass struggle to reach the three of the aforementioned Bourdieusian capitals beside symbolic capital, they try in vain. Because the competition between the classes is so hard that it becomes impossible for a debased culture to convert from one capital to another in order to gain much more power in any sphere of life.

Last but not least, the male and female characters in the novel employ distinctive manners and perceptions in conformity with the Edwardian cultural codes and societal norms, whose roots are threatened by the effects of modernity. Yet again, it is discernible that while the upper class Wilcoxes show economic capital higher than cultural and social capital, the intellectual upper-middle class Schlegels exhibit cultural capital rather than economic and social capital. Furthermore, the working class Basts struggle to convert their economic, social and cultural capital even if they are unable to do so. As these illustrations suggest, Bourdieusian cultural habitus becomes the main source of converting one's cultural capital into other forms of capital as well.

\section{REFERENCES}

Bourdieu, P. (1977). Outline of a theory of practice. Cambridge: Cambridge University Press.

Bourdieu, P. (1984). Distinction: A social critique of the judgment of taste. (Trans.) Richard Nice. Cambridge, MA: Harvard UP.

Bourdieu, P. (1986). "The forms of capital" in Richardson, J., Handbook of Theory and Research for the Sociology of Education. Westport, CT: Greenwood, 241-58.

Bourdieu, P. (1990). In other words: Essays towards a reflexive sociology. Polity Press: Cambridge.

Bradbury, M. (1966). Two passages to India: Forster as Victorian and modern. Bradbury, Malcolm (ed.) E. M. Forster: A Collection of Critical Essays. New Jersey: Prentice Hall.

Crews, F. C. (1967). E. M. Forster: The perils of humanism. Princeton: Princeton UP.

Firchow, P. E. (1981). Germany and Germanic mythology in Howards End. 
Comparative Literature, 33(1), 50-68.

Forster, E. M. (1947). The collected tales of E. M. Forster. New York: Alfred A. Knopf, A Borzoi Book, "The Eternal Moment".

Forster, E. M. (2007). Howards End. electronic classic series, Pennsylvania State University. ( $1^{\text {st }}$ pub. 1910 by Edward Arnold, London).

Frank, K. (2009). Concerning E. M. Forster. London: Weidenfeld \& Nicolson.

Gordon, M. (2004). "Things that can't be phrased": Forster and Howards End, Salmagundi, 143, 89-103.

Lucas, J. (1997). Discovering England: The view from the train, Literature and History, 6(2), 37-55.

Madran, C. Y. (2004). An archetypal analysis of E. M Forster's fiction. Middle East Technical University. Unpublished Doctoral Dissertation.

Richard, O. (1990). Heralds of modernity: Cars and planes from invention to necessity. in M. Teich and Roy Porter (eds.), Fin de Siècle and its Legacy, Cambridge.

Rose, J. (2001). The intellectual life of the British working classes. New Haven: Yale University Press.

Sugate, A. S. (2012). The novels of E. M. Forster: A thematic study. Unpublished Doctoral Dissertation.

Thacker, A. (2000). E. M. Forster and the motor car. Literature \& History, 9(2), 37 52.

Turner, H. S. (2000) Empires of objects: Accumulation and entropy in E. M. Forster's Howards End. Twentieth-Century Literature. 46(3), 328-45.

White, L. (2005). Vital disconnection in "Howards End". Twentieth Century Literature, 51(1), 43-63. 
